\title{
Simultaneous estimation of the nutritional contribution of fish meal, soy protein isolate and corn gluten to the growth of Pacific white shrimp (Litopenaeus vannamei) using dual stable isotope analysis
}

\author{
Julián Gamboa-Delgado *, Mónica G. Rojas-Casas, Martha G. Nieto-López, Lucía Elizabeth Cruz-Suárez \\ Programa Maricultura, Departamento de Ecología, Facultad de Ciencias Biológicas, Universidad Autónoma de Nuevo León, A.P. F-67. San Nicolás de los Garza N.L. 66451, México
}

\section{A R T I C L E I N F O}

\section{Article history:}

Received 11 September 2012

Received in revised form 26 November 2012

Accepted 27 November 2012

Available online 4 December 2012

\section{Keywords:}

Stable isotopes

Nutrient contribution

Fish meal

Soy protein

Corn gluten

Litopenaeus vanname

\begin{abstract}
A B S T R A C T
The nutritional contribution of the dietary nitrogen, carbon and total dry matter supplied by fish meal (FM), soy protein isolate (SP) and corn gluten (CG) to the growth of Pacific white shrimp Litopenaeus vannamei was assessed by means of isotopic analyses. As SP and CG are ingredients derived from plants having different photosynthetic pathways which imprint specific carbon isotope values to plant tissues, their isotopic values were contrasting. FM is isotopically different to these plant meals with regards to both, carbon and nitrogen. Such natural isotopic differences were used to design experimental diets having contrasting isotopic signatures. Seven isoproteic ( $36 \%$ crude protein), isoenergetic $\left(4.7 \mathrm{kcal} \mathrm{g}^{-1}\right.$ ) diets were formulated; three diets consisted in isotopic controls manufactured with only one main ingredient supplying dietary nitrogen and carbon: 100\% FM (diet 100F), 100\% SP (diet 100S) and 100\% CG (diet 100G). Four more diets were formulated with varying mixtures of these three ingredients, one included $33 \%$ of each ingredient on a dietary nitrogen basis (diet 33FSG) and the other three included a proportion 50:25:25 for each of the three ingredients (diets 50FSG, 50SGF and 50GFS). At the end of the bioassay there were no significant differences in growth rate in shrimps fed on the four mixed diets and diet $100 \mathrm{~F}(k=0.215-0.224)$. Growth rates were significantly lower ( $k=0.163-0.201)$ in shrimps grown on diets containing only plant meals. Carbon and nitrogen stable isotope values $\left(\delta^{13} \mathrm{C}\right.$ and $\left.\delta^{15} \mathrm{~N}\right)$ were measured in experimental diets and shrimp muscle tissue and results were incorporated into a three-source, two-isotope mixing model. The relative contributions of dietary nitrogen, carbon and total dry matter from FM, SP and CG to growth were statistically similar to the proportions established in most of the diets after correcting for the apparent digestibility coefficients of the ingredients. Dietary nitrogen available in diet 33FSG was incorporated in muscle tissue at proportions representing 24, 35 and $41 \%$ of the respective ingredients. Diet 50GSF contributed significantly higher amounts of dietary nitrogen from CG than from FM. When the level of dietary nitrogen derived from FM was increased in diet 50FSG, nutrient contributions were more comparable to the available dietary proportions as there was an incorporation of 44, 29 and 27\% from FM, SP and CG, respectively. Nutritional contributions from SP were very consistent to the dietary proportions established in the experimental diets.
\end{abstract}

(c) 2012 Elsevier B.V. All rights reserved.

\section{Introduction}

Information gathered from traditional nutritional assays in conjunction with data from chemical analyses of diets and animal tissues provides valuable information to infer on the dietary performance of specific ingredients. Among these chemical analyses, the use of stable isotopes represents an additional tool for nutritional studies conducted on aquatic species. The integration of isotopic data into isotopic mixing models has made possible to convert the isotopic values of consumers

\footnotetext{
* Corresponding author. Tel./fax: +52 8183526380 .

E-mail addresses: julian.gamboad@uanl.mx, jgam97@yahoo.com (J. Gamboa-Delgado).
}

and their different trophic elements to dietary contributions (Phillips, 2012). In the fields of ecology and nutrition, the isotopic techniques have provided an improved understanding of how organisms incorporate the elements they consume. In this context, it has been pointed out that animal tissue often does not reflect the bulk isotopic composition of the diet, but the isotopic composition of the dietary components from which the tissue was biosynthesized (Gannes et al., 1997; Newsome et al., 2011). In aquaculture nutrition, the natural isotope ratios of nitrogen and carbon $\left({ }^{15} \mathrm{~N} /{ }^{14} \mathrm{~N}\right.$ and ${ }^{13} \mathrm{C} /{ }^{12} \mathrm{C}$, respectively measured and reported in delta notation as $\delta^{15} \mathrm{~N}$ and $\delta^{13} \mathrm{C}$ ) have been used as natural biomarkers to estimate dietary contributions in organisms fed either on different types of live food and inert diets, or raised on formulated diets having ingredients with contrasting isotopic signatures (Gamboa-Delgado and Le Vay, 2009a, 2009b; Gamboa-Delgado 
et al., 2008; Jomori et al., 2008; Martínez-Rocha et al., in press; Matsuda et al., 2009).

Partial or total replacement of fish meal in aquaculture diets represents important advantages in economical and ecological terms. The progressively higher production of several aquaculture species is in turn exerting a higher demand for aquafeeds. Among these mass-produced marine animals, the Pacific white shrimp Litopenaeus vannamei has become the main shrimp species produced through aquaculture practices since 2003 (FAO, 2007). Hence, numerous nutritional studies conducted on this species have focused on testing different plant-derived meals and purified, isolated plant proteins as dietary ingredients to replace fish meal (e.g. Amaya et al., 2007; Harter et al., 2011; Liu et al., 2012; Oujifard et al., 2012). Different dietary resources found in the aquatic and terrestrial ecosystems frequently show distinct isotopic values due to the effect of characteristic nutrient flows and metabolic pathways. This natural isotopic labeling allows conducting studies aimed to elucidate the nutritional contribution of specific dietary sources to the growth of a consuming organism. Plants exhibit three different photosynthetic pathways (C3, C4 and CAM), which imprint different isotopic values to vegetal tissues. For example, soy is a C3 or Calvin cycle plant (called C3 because during photosynthesis, the first product of $\mathrm{CO}_{2}$ fixation is a 3-carbon compound), while corn is a C4 or Hatch-Slack cycle plant (Leegood, 2002). The reaction kinetics of these photosynthetic pathways has a significant influence on the carbon isotopic values $\left(\delta^{13} \mathrm{C}\right)$ of each type of plant. C3 plants have a mean $\delta^{13} \mathrm{C}$ value of $-29 \%$, while C4 plants show a more isotopically-enriched, mean $\delta^{13} \mathrm{C}$ value of $-13 \%$ (Ehleringer and Cerling, 2001; O'Leary, 1988). In the case of $\delta^{15} \mathrm{~N}$ values, most plants have isotopic values ranging from 2 to $6 \%$; however, the nitrogen isotope values of most traditional crops are strongly influenced by the $\delta{ }^{15} \mathrm{~N}$ values of the inorganic fertilizers used to grow them. As the isotopic mixing models are able to estimate dietary contributions at higher resolution when the nutrient sources are isotopically distinct (Phillips, 2012), the isotopic values of primary producers have been systematically manipulated using specific fertilizers (Gamboa-Delgado et al., 2011; Le Vay and Gamboa-Delgado, 2011). The present study employed the natural isotopic differences found in soy protein isolate, corn gluten and fish meal, to simultaneously assess the relative incorporation of dietary nitrogen, carbon and total dry matter supplied by these three sources to the muscle tissue of Pacific white shrimp. In addition, the nitrogen and carbon half times in muscle tissue of shrimps fed on the different experimental diets were estimated.

\section{Material and methods}

\subsection{Experimental animals}

Pacific white shrimp (L. vannamei) postlarvae were obtained from a commercial hatchery (Maricultura del Pacífico) located in Mazatlán, Mexico. After reception, animals were placed in $500 \mathrm{~L}$ tanks and acclimated for $20 \mathrm{~d}$ to a bioassay room under the following conditions: seawater temperature $30.2 \pm 0.7^{\circ} \mathrm{C}$, salinity $35.4 \pm 0.7 \mathrm{~g} \mathrm{l}^{-1}, \mathrm{pH} 8.4 \pm$ 0.1 and saturated dissolved oxygen. Total ammonia nitrogen $(0.09 \pm$ $0.06 \mathrm{mg} / \mathrm{L})$, nitrite (not detected), and nitrate $(12.9 \pm 4.6 \mathrm{mg} / \mathrm{L})$ were monitored using a commercial kit (FasTest; Aquarium Systems, Sarrebourg, France). A photoperiod was set up to provide a light:dark ratio of $10: 14 \mathrm{~h}$. During the acclimation period, shrimps were exclusively fed a crumbled commercial compound diet (35\% protein, Grupo Costamar, Hermosillo, Mexico) that established a known isotopic baseline in shrimp tissue before the start of the experiment. It has been demonstrated that fast-growing postlarval Penaeid shrimps achieve isotopic equilibrium with their respective diets in 15 to $20 \mathrm{~d}$ (Gamboa-Delgado and Le Vay, 2009a; Gamboa-Delgado et al., 2011). The commercial diet was analyzed for nitrogen and carbon content and their respective isotopic values $\left(\delta^{15} \mathrm{~N}\right.$ and $\left.\delta^{13} \mathrm{C}\right)$ before the experimental feeding trial.

\subsection{Experimental diets}

Seven isonitrogenous (36\% crude protein) and isoenergetic (4.7 $\mathrm{kcal} \mathrm{g}^{-1}$ ) experimental compound diets were formulated with different proportions of fish meal (FM), soy protein isolate (SP) and corn gluten (CG) (Table 1). The software Nutrion (Nutrion Software, Chapala, Mexico) was used to assist with the formulation of experimental diets. Diets were not manufactured to conduct an ingredientsubstitution study; instead, they were formulated with ingredients having contrasting isotopic values to explore their nutritional contributions to shrimp growth as described below. Three diets were formulated with only one ingredient supplying dietary nitrogen: 100\% FM (diet 100F), 100\% SP (diet 100S) and 100\% CG (diet 100G). These diets were used as isotopic controls to correct for the isotopic differences between diets and consumers (isotopic discrimination factors) after having reached dietary equilibrium. The other four diets were formulated with varying mixtures of FM, SP and CG, one included $33 \%$ of each ingredient on a dietary nitrogen basis (diet 33FSG) and the other three included a proportion of 50:25:25 for each of the respective three ingredients (diets 50FSG, 50SFG and 50GFS). Before manufacturing the diets, macronutrients were finely ground using a Pulvex 200 grinder fitted with a size \#35 mesh. Micronutrients were weighed to the nearest $\mathrm{mg}$, hand-mixed for $5 \mathrm{~min}$ and added to the macronutrients, which in turn were homogenized for 15 min using a commercial blender. Lecithin was dissolved in pre-weighed, warm fish oil and added to the mixture. The dough was extruded through a die plate having orifices of $1.4 \mathrm{~mm}$ in diameter. Strands were collected on wire trays and post-conditioned by 5 min autoclaving (18.5 psi, $125^{\circ} \mathrm{C}$ ) to reduce nutrient leaching rates. Diets containing plant meals as the only protein source were sprayed-coated with a hydrolyzed protein to improve palatability. Diets were dried in a convection oven for $8 \mathrm{~min}$ at $100{ }^{\circ} \mathrm{C}$ and stored at $4{ }^{\circ} \mathrm{C}$. Proximal analyses of the experimental diets included moisture content (method AOAC 930.15), protein content (Dumas method, LECO) and lipid content (Soxhlet system HT-1045, method AOAC 996.06) (Tecator, 1983). The energy content of the ingredients was estimated using a semi-micro bomb calorimeter (Parr 1425 PIC, Illinois, USA).

\subsection{Experimental design and rearing system}

Shrimps having an initial mean wet weight of $162 \pm 36 \mathrm{mg}$ were distributed in 21, 60-L capacity tanks. Twenty animals were placed in triplicate tanks after conducting a pre-selection aimed to allocate animals with the same size distribution pattern in each unit. The experimental tanks having built-in air lifts are connected to a recirculation system holding artificial seawater (Fritz, Chemical Co., Texas, USA). Seawater was exchanged in every tank at a rate of $800 \% \mathrm{~d}^{-1}$ and it was treated by mechanical cartridge filters, UV filter, protein skimmers and a bubble bead biological filter. The experimental tank array is designed so that possible water quality variations affect all tanks simultaneously. Animals were fed the experimental compound diets at daily amounts representing 10 to $15 \%$ of the animal biomass. Feed was delivered in four rations at 8:00, 12:00, 16:00 and 20:00 $\mathrm{h}$ for 29 days. Before the first feeding ration, uneaten feed, feces and moults were siphoned out daily. Tank walls were periodically scrubbed off with a rough fiber to avoid any possible biofilm growth. The experimental time period and sampling points to collect muscle samples for isotopic analysis were defined according to the exponential rate of isotopic change previously observed in experiments using small-sized Penaeid shrimp (Gamboa-Delgado et al., 2011; Martínez-Rocha et al., in press). In order to verify isotopic values shifting in time to isotopic equilibrium, on experimental days $0,2,4,8,15$ and 22 , one shrimp was randomly collected from each replicate tank, killed in ice/water slurry and dissected to isolate the abdominal muscle. The exoskeleton and hind gut were removed, muscle tissue samples were rinsed with distilled water and stored in Eppendorf tubes at $-80{ }^{\circ} \mathrm{C}$ until sample pretreatment. As 
Table 1

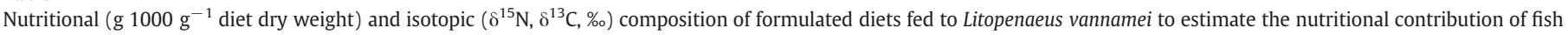
meal $(F)$, soy protein isolate $(S)$ and corn gluten $(G)$ to shrimp muscle tissue.

\begin{tabular}{|c|c|c|c|c|c|c|c|}
\hline Ingredient/diet & $100 \mathrm{~F}$ & $100 \mathrm{~S}$ & $100 G$ & 33FSG & 50FSG & 50SFG & 50GFS \\
\hline Fish meal $^{\mathrm{a}}$ & 556.2 & 0.0 & 0.0 & 180.0 & 278.0 & 139.0 & 139.0 \\
\hline Soy protein isolate ${ }^{\mathrm{b}}$ & 0.0 & 449.5 & 0.0 & 149.0 & 112.0 & 224.9 & 112.1 \\
\hline Corn gluten ${ }^{c}$ & 0.0 & 0.0 & 600.2 & 199.0 & 150.7 & 150.0 & 300.5 \\
\hline Wheat starch ${ }^{\mathrm{d}}$ & 348.8 & 390.7 & 253.5 & 348.1 & 348.1 & 354.3 & 323.4 \\
\hline Lecithin ${ }^{\mathrm{e}}$ & 35.0 & 54.1 & 54.5 & 45.4 & 40.6 & 47.4 & 47.5 \\
\hline Fish oil $^{\mathrm{a}}$ & 24.0 & 34.6 & 10.4 & 26.3 & 27.9 & 28.3 & 22.2 \\
\hline Disodium phosphate ${ }^{\mathrm{f}}$ & 0.0 & 20.2 & 41.0 & 10.8 & 0.0 & 12.5 & 17.7 \\
\hline Cellulose $\mathrm{f}^{\mathrm{f}}$ & 7.0 & 20.6 & 10.0 & 12.0 & 13.7 & 14.1 & 7.9 \\
\hline Alginate $^{f}$ & 20.0 & 20.0 & 20.0 & 20.0 & 20.0 & 20.0 & 20.0 \\
\hline Vitamin premix ${ }^{\mathrm{a}}$ & 2.5 & 2.5 & 2.5 & 2.5 & 2.5 & 2.5 & 2.5 \\
\hline Mineral premix ${ }^{a}$ & 2.5 & 2.5 & 2.5 & 2.5 & 2.5 & 2.5 & 2.5 \\
\hline Choline chloride ${ }^{a}$ & 2.0 & 2.0 & 2.0 & 2.0 & 2.0 & 2.0 & 2.0 \\
\hline Cholesterol $^{\mathrm{g}}$ & 0.0 & 1.2 & 1.5 & 0.4 & 0.0 & 0.6 & 0.7 \\
\hline Vitamin $C^{\mathrm{a}}$ & 1.0 & 1.0 & 1.0 & 1.0 & 1.0 & 1.0 & 1.0 \\
\hline Antioxidant $\mathrm{t}^{\mathrm{a}}$ & 0.5 & 0.5 & 0.5 & 0.5 & 0.5 & 0.5 & 0.5 \\
\hline Antifungic agent ${ }^{\mathrm{a}}$ & 0.5 & 0.5 & 0.5 & 0.5 & 0.5 & 0.5 & 0.5 \\
\hline Total & 1000 & 1000 & 1000 & 1000 & 1000 & 1000 & 1000 \\
\hline \multicolumn{8}{|c|}{ Proximal and isotopic analysis } \\
\hline Crude protein $\left(\mathrm{g} \mathrm{kg}^{-1}\right)$ & 362 & 356 & 365 & 356 & 367 & 353 & 362 \\
\hline Lipids $\left(\mathrm{g} \mathrm{kg}^{-1}\right)$ & 83 & 80 & 84 & 83 & 80 & 81 & 84 \\
\hline Gross energy (kcal g ${ }^{-1}$ ) & 4.6 & 4.8 & 4.6 & 4.7 & 4.7 & 4.8 & 4.7 \\
\hline$\delta{ }^{15} \mathrm{~N}(\%)$ & 16.5 & 0.6 & 3.1 & 6.4 & 9.0 & 5.1 & 5.9 \\
\hline$\delta^{13} \mathrm{C}(\% \circ)^{\mathrm{h}}$ & -19.5 & -25.1 & -16.6 & -20.1 & -20.4 & -21.7 & -19.3 \\
\hline
\end{tabular}

${ }^{a}$ Alimentos Costamar (Sonora, Mexico).

${ }^{\mathrm{b}}$ American Soybean Association (St. Louis, MO, USA).

'Trow Nutrition International (Putten, The Netherlands).

dAlmidones y gluten S.A. (Monterrey, Mexico).

${ }^{\text {e}}$ Ragasa Industrias S.A. de C.V. (Monterrey, Mexico).

fSigma-Aldrich (St. Louis, MO, USA).

g'Solvay Pharmaceuticals (Houston, TX, USA).

${ }^{\mathrm{h}}$ After lipid extraction and uncorrected for isotopic discrimination factors.

an estimate of growth $(k)$ is required for the exponential model of isotopic change, the individual wet weight of five animals per replicate was determined on the sampling days using a digital balance. Animals were captured with nets and weighed after blotting off excess water with a moist cloth. At the end of the experiment (day 29), all the remaining animals were killed and three shrimps per replicate tank (9 per treatment) were also weighed, sacrificed and dissected to obtain abdominal muscle tissue.

\subsection{Sample pretreatment and stable isotope analyses}

Samples of shrimp muscle tissue and compound diets were dehydrated at $50{ }^{\circ} \mathrm{C}$ until constant weight in a convection oven. Dry samples were manually ground using mortar and pestle to obtain a fine powder. In order to avoid sample loss, small muscle samples (e.g. those belonging to shrimps sampled on the first experimental week or showing slow growth) were not ground, instead, fragments of dry muscle tissue were obtained for isotopic analysis. Lipids are usually depleted in ${ }^{13} \mathrm{C}$ relative to carbohydrates and protein (De Niro and Epstein, 1978; Stenroth et al., 2006); therefore, in order to reduce the variability of $\delta^{13} \mathrm{C}$ values and allow further comparisons, diet samples ( $8 \%$ lipid content) were lipid extracted following Beaudoin et al. (2001) by suspending the ground material in a 50:50 solution of chloroform-methanol for $12 \mathrm{~h}$. Samples were solvent-treated twice over this period of time. After lipid extraction samples were oven-dried ( $50{ }^{\circ} \mathrm{C}$ until constant weight), homogenized again, and kept in a desiccator. Muscle tissue samples were not lipid extracted as part of the pre-treatment as shrimp muscle contains low lipid levels and it has been shown that $\delta^{15} \mathrm{~N}$ values in muscle tissue of decapod crustaceans undergo minimal, no significant changes after solvent treatment (Bodin et al., 2007; Stenroth et al., 2006). Diet and muscle tissue samples of 900 to $1100 \mu \mathrm{g}$ were packed in tin cups (D1008 Elemental Microanalysis Ltd., UK) and organized in 96-well microplates.
Samples were analyzed at the Stable Isotope Facility of the Department of Plant Sciences, University of California, (Davis, CA, USA) using a PDZ Europa Scientific Roboprep elemental analyzer coupled to a PDZ Europa Hydra 20/20 stable isotope ratio mass spectrometer (Crewe, UK). Repeated measurements of two calibration standards indicated that instrument precision (SD) was $0.08 \%$ for $\delta^{15} \mathrm{~N}$ and $0.14 \%$ 。 for $\delta^{13} \mathrm{C}$. Isotopic results are expressed in delta notation $(\delta)$, which is defined as part per thousand (\%) deviations from the $\delta^{15} \mathrm{~N}$ and $\delta^{13} \mathrm{C}$ values of the isotopic standard reference materials (atmospheric nitrogen and Pee Dee belemnite, respectively). We employ the term "discrimination factor" following Cherel et al. (2005) and Dennis et al. (2010) to describe changes in isotopic values between a consuming organism (whole body or specific tissue) and its diet after having reached isotopic equilibrium $\left(\Delta^{15} \mathrm{~N}\right.$ or $\left.\Delta^{13} \mathrm{C}\right)$.

\subsection{Estimation of nutrient contribution and elemental residency times} in tissue

A three-source, two-isotope mixing model (Phillips and Koch, 2002) was applied to estimate the relative contribution of dietary nitrogen, carbon and total dry matter supplied by FM, SP and CG to the muscle tissue of shrimps under the different dietary treatments. The model considers the isotopic differences between the sources (in this particular study represented by the ingredients FM, SP and CG) and the mixture (shrimp muscle tissue). One of the model assumptions indicates that the consuming organism is in isotopic equilibrium with its diet, this assumption was verified by measuring the isotopic values in shrimp muscle throughout the experimental period and until asymptotic values were reached. Additional assumptions associated to the use of isotopic mixing models and the validation of results (Gannes et al., 1997; Martínez del Rio and Wolf, 2005; Martínez del Rio et al., 2009; Post, 2002) were also met or taken into consideration in interpreting the results. These include 
similar (or known, in order to correct for) elemental composition of the food sources (dietary ingredients), estimation of discrimination factors and consideration of isotopic routing and dietary assimilation efficiencies. Estimation of isotopic discrimination factors $\left(\Delta^{15} \mathrm{~N}\right.$ and $\Delta^{13} \mathrm{C}$ ) increases the accuracy of the estimated dietary contributions by integrating correction factors into the mixing model (Martínez del Rio et al., 2009; Phillips, 2012). In the present study, measured isotope values were corrected for discrimination factors by introducing into the model three reference isotopic values determined in muscle tissue of shrimps fed exclusively on diets containing only FM, SP or CG. Previous studies have shown that FM, SP and CG have different apparent digestibility coefficients (ADC) for protein $(0.78$, 0.96 and 0.81 , respectively) and dry matter $(0.66,0.92$ and 0.83 , respectively) when fed to L. vannamei (Cruz-Suárez et al., 2009; Terrazas et al., 2010; Villarreal-Cavazos, 2011). Therefore, expected dietary proportions of dietary nitrogen, carbon and total dry matter were corrected for ADC before comparisons to observed proportions determined in muscle tissue were conducted. Considering that the carbon and nitrogen isotopes found in amino acids reflect both, diet composition and metabolic processes (Boecklen et al., 2011) and the majority of deposited carbon in muscle tissue is derived from amino acids, corrections applied for the ADC of dietary protein (nitrogen) were also applied to dietary carbon. $\delta^{13} \mathrm{C}$ and $\delta^{15} \mathrm{~N}$ values measured in shrimp muscle tissue were sequentially introduced into the model to estimate the relative proportion of dietary nitrogen, carbon and dry matter incorporated from the three main ingredients. An indicator of the variability of nutritional contributions was generated by introducing into the isotopic mixing model isotope values measured in individual animals and not averaged values. Preliminary analysis indicated that elemental contents in FM, SP and CG were significantly different $(\mathrm{N}=10.5 \pm 0.4,13.8 \pm 0.3$ and $10.7 \pm 0.7 \%$, respectively, and $\mathrm{C}=$ $39.3 \pm 0.4,47.2 \pm 0.7$ and $52.1 \pm 1.7 \%$, respectively). Elemental contents are also considered by the mixing model to obtain estimates of the relative contribution of dry matter from the food sources to growth. $\delta^{15} \mathrm{~N}$ and $\delta^{13} \mathrm{C}$ values were determined at different times of the experimental period and these values were introduced into an exponential model of isotopic change (Hesslein et al., 1993) as described in Gamboa-Delgado et al. (2011). The model provides a quantitative coefficient $(m)$ that allows distinguishing the isotopic change that is due to growth $(k)$ and/or metabolic turnover $(m)$. Coefficients $k$ and $m$ in turn provide an indicator of the residency time (Eq. (1)), the time period necessary for half of the muscle nitrogen or carbon to be replaced after animals consume a new diet (half time, $t_{50}$ ) (MacAvoy et al., 2005).

$t_{50}=\operatorname{In} 2 / m+k$

\subsection{Statistical analyses}

Nitrogen and carbon contents of dietary ingredients and their respective $\delta^{15} \mathrm{~N}$ and $\delta^{13} \mathrm{C}$ values, dietary effects on isotopic values of muscle tissue at different times, and mean shrimp wet weight were analyzed by one way ANOVA after normal distribution and data homoscedasticity were verified. Tukey pair wise comparisons were used to detect treatments significantly differing from each other. Survival data lacked homoscedasticity after transformation and comparisons were done using a Kruskal-Wallis test. Chi-square goodness of fit tests $\left(\chi^{2}\right)$ were applied to compare expected (dietary proportions of nutrients contributed by FM, SP and CG after correcting for ADC) and observed (estimated proportions incorporated in muscle tissue) dietary proportions of incorporated nutrients. Parameter $m$ in the exponential model of isotopic change was estimated by iterative non-linear regression. All tests were done using SPSS 17.0 software (SPSS Inc.) at a significance level of $P<0.05$.

\section{Results}

\subsection{Shrimp growth and survival}

During the experimental feeding period, water quality parameters remained within the recommended optimal values for this species. Temperature, $\mathrm{pH}$, salinity, dissolved oxygen and nitrogenous waste concentrations were maintained as the previously described conditions for the bioassay room. At the end of the experiment, shrimps reared under the seven experimental treatments showed similar survival rates $(93 \pm 6 \%$ ) but significantly different mean final wet weights (Table 2). Shrimp fed diet $100 \mathrm{~F}$ and those fed the four mixed diets containing the three ingredients at different inclusion levels showed statistically similar final weights. From these treatments, animals fed on diets 50SFG and 50GFS showed lower growth rates. Growth rates were significantly lower in shrimps fed diets containing only SP or only CG as nitrogen source.

\subsection{Isotopic shifts and discrimination factors}

SP and CG showed very contrasting $\delta^{15} \mathrm{~N}(0.6 \pm 0.2$ and $3.0 \pm 0.1 \%$, respectively) and $\delta^{13} \mathrm{C}$ values ( $-25.5 \pm 0.4$ and $-13.5 \pm 0.1 \%$, respectively). Isotopic values in plant sources were also significantly different when compared to the isotopic values of FM $\left(\delta^{15} \mathrm{~N}=16.6 \pm 0.2 \%\right.$ and $\delta{ }^{13} \mathrm{C}=-16.9 \pm 0.4 \%$ o). These significant differences allowed formulating diets having ingredients with isotopically contrasting values that in turn elicited a wide range of nitrogen and carbon isotope changes in muscle tissue (Fig. 1a and b). All mixed experimental diets exerted a rapid influence on the isotopic values of shrimp tissue and by day 22 , animals in all treatments (including those in the three isotopic control diets) had reached isotopic equilibrium with their feed. $\Delta^{15} \mathrm{~N}$ and $\Delta^{13} \mathrm{C}$ values between animals and their respective diets were significantly different (Table 3). $\Delta^{15} \mathrm{~N}$ values between muscle tissue and diet $100 \mathrm{~F}$ were small $(0.3 \%)$, while values observed in shrimps fed on diets $100 \mathrm{~S}$ and $100 \mathrm{G}$ were significantly larger (5.3 and $5.8 \%$, respectively). In contrast, overall $\Delta^{13} \mathrm{C}$ values were less variable and ranged from -0.1 to $2.8 \%$. The high range of isotopic values in the three main dietary ingredients being reflected in shrimp muscle tissue increased the resolution when assessing total dry matter contributions and nitrogen and carbon residency times in tissue. However, after applying correction factors for isotopic discriminations, the $\delta^{15} \mathrm{~N}$ values of some diets approached to the $\delta^{15} \mathrm{~N}$ values of shrimp tissue and isotopic changes did not describe exponential trends (Fig. 1a).

\subsection{Nitrogen and carbon half times in tissue}

Nitrogen and carbon isotopic shifts followed an expected pattern characterized by an exponential trend caused by the isotopic values of the experimental diets being reflected in shrimp muscle tissue. For most treatments, predicted isotopic values fitted well on the observed data and from these data, parameter $m$ (metabolic turnover) was estimated by means of iterative non-linear regression. Although

Table 2

Final wet weight (FW), weight gain (WG), specific growth rate (SGR) and survival rate of Pacific white shrimp L. vannamei reared under diets having different dietary proportions of fish meal, soy protein isolate and corn gluten.

\begin{tabular}{llccc}
\hline Diet & FW $(\mathrm{mg})$ & WG $(\%)$ & SGR $\left(\% \mathrm{~d}^{-1}\right)$ & Survival $(\%)$ \\
\hline 100F & $804 \pm 348^{\mathrm{a}}$ & $404 \pm 96^{\mathrm{a}}$ & $5.58 \pm 0.61^{\mathrm{a}}$ & $96 \pm 6^{\mathrm{a}}$ \\
100S & $508 \pm 189^{\mathrm{b}}$ & $214 \pm 49^{\mathrm{bc}}$ & $3.95 \pm 0.54^{\mathrm{b}}$ & $93 \pm 6^{\mathrm{a}}$ \\
100G & $276 \pm 79^{\mathrm{c}}$ & $72 \pm 32^{\mathrm{c}}$ & $1.87 \pm 0.64^{\mathrm{c}}$ & $93 \pm 13^{\mathrm{a}}$ \\
33FSG & $839 \pm 301^{\mathrm{a}}$ & $419 \pm 53^{\mathrm{a}}$ & $5.68 \pm 0.34^{\mathrm{a}}$ & $96 \pm 6^{\mathrm{a}}$ \\
50FSG & $816 \pm 310^{\mathrm{a}}$ & $407 \pm 101^{\mathrm{a}}$ & $5.60 \pm 0.63^{\mathrm{a}}$ & $93 \pm 6^{\mathrm{a}}$ \\
50SFG & $724 \pm 256^{\mathrm{a}}$ & $343 \pm 58^{\mathrm{ab}}$ & $5.14 \pm 0.41^{\mathrm{ab}}$ & $100 \pm 0^{\mathrm{a}}$ \\
50GFS & $682 \pm 233^{\mathrm{ab}}$ & $317 \pm 20^{\mathrm{ab}}$ & $4.93 \pm 0.16^{\mathrm{ab}}$ & $89 \pm 11^{\mathrm{a}}$ \\
\hline
\end{tabular}

Different superscripts indicate significant differences for that particular column. 
a)

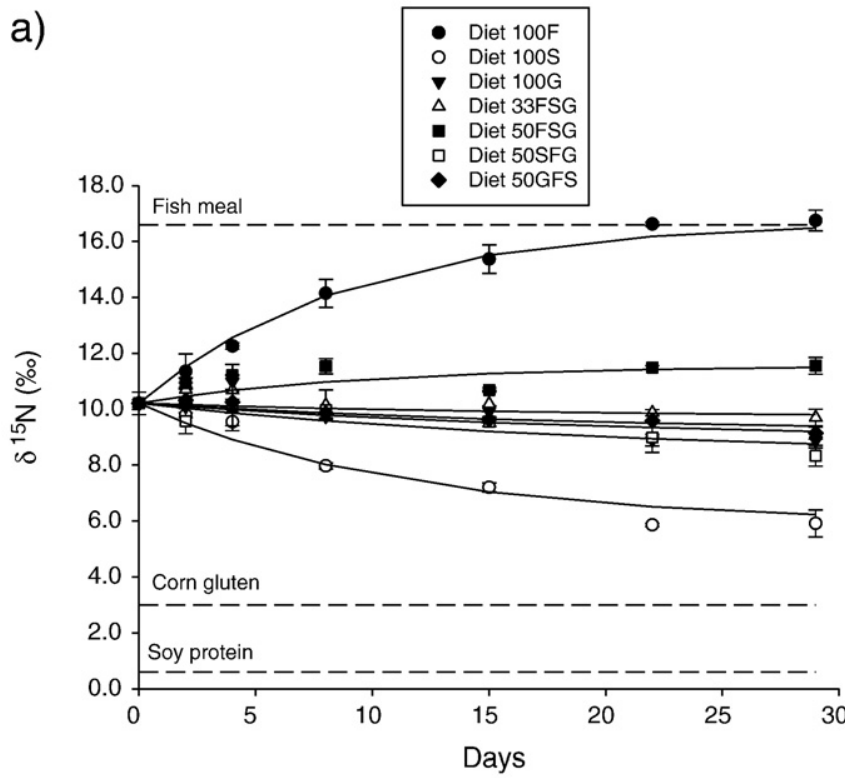

b)

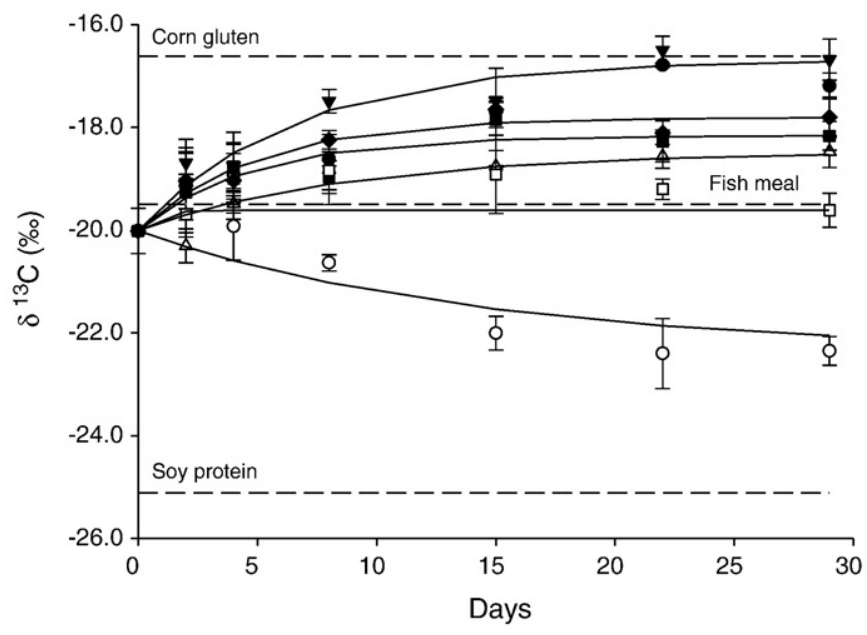

Fig. 1. Changes in nitrogen (a) and carbon (b) stable isotope values in muscle tissue of white shrimp L. vannamei reared on experimental diets having different proportions of fish meal, soy protein isolate and corn gluten. Dotted lines represent the isotopic values of control diets containing only one nitrogen source. Solid lines indicate predicted isotopic values generated by an exponential model of isotopic change (Hesslein et al., 1993 ) and show the best fit to observed data. Mean of 3 to 9 animals per sample \pm SD.

Table 3

Mean growth rates $(k)$ and estimated half times of nitrogen and carbon in muscle tissue of Pacific white shrimp L. vannamei reared under diets having different dietary proportions of fish meal, soy protein and corn gluten. $\Delta^{15} \mathrm{~N}$ and $\Delta{ }^{13} \mathrm{C}$ represent the isotopic difference between diets and muscle tissue after isotopic equilibrium was reached.

\begin{tabular}{|c|c|c|c|c|c|c|c|}
\hline \multicolumn{2}{|l|}{ Diet } & \multirow{2}{*}{$\frac{\text { Nitrogen }}{\text { Half time (d) }}$} & \multicolumn{4}{|c|}{ Carbon } & \multirow[b]{2}{*}{$\Delta^{13} \mathrm{C}$} \\
\hline & $k\left(\mathrm{~d}^{-1}\right)$ & & $\mathrm{R}^{2}$ & $\Delta^{15} \mathrm{~N}$ & Half time $(\mathrm{d})$ & $\mathrm{R}^{2}$ & \\
\hline $100 \mathrm{~F}$ & $0.056 \pm 0.004^{\mathrm{a}}$ & $6.2 \pm 0.7^{\mathrm{a}}$ & 99 & 0.3 & $6.4 \pm 0.9^{\mathrm{ab}}$ & 83 & 2.3 \\
\hline $100 \mathrm{~S}$ & $0.039 \pm 0.007^{b}$ & $7.8 \pm 1.1^{\mathrm{a}}$ & 95 & 5.3 & $9.8 \pm 2.1^{\mathrm{b}}$ & 74 & 2.8 \\
\hline $100 G$ & $0.019 \pm 0.006^{c}$ & - & - & 5.8 & $4.5 \pm 0.4^{\mathrm{a}}$ & 93 & -0.1 \\
\hline 33FSG & $0.057 \pm 0.003^{\mathrm{a}}$ & - & - & 3.3 & $6.2 \pm 1.2^{\mathrm{ab}}$ & 86 & 1.7 \\
\hline 50FSG & $0.056 \pm 0.004^{\mathrm{a}}$ & $6.6 \pm 1.3^{a}$ & 49 & 2.5 & $3.3 \pm 0.7^{\mathrm{a}}$ & 87 & 2.2 \\
\hline 50SFG & $0.051 \pm 0.005^{\mathrm{a}}$ & - & - & 3.2 & - & - & 2.1 \\
\hline 50GFS & $0.049 \pm 0.008^{\mathrm{ab}}$ & - & - & 3.2 & $3.4 \pm 0.5^{\mathrm{a}}$ & 93 & 1.5 \\
\hline
\end{tabular}

Different superscripts indicate significant differences for that particular column. $\mathrm{R}^{2}$ values indicate the degree of fitness of data generated by the exponential model of isotopic change and isotopic values measured in shrimp muscle tissue. isotopic differences between the conditioning diet and the experimental diets were significant, it was not possible to estimate the nitrogen half times for all diets because after applying corrections for isotopic discrimination factors, isotopic differences between shrimp and diets were narrowed down. Due to this, diets 50SFG and 50GFS did not cause exponential nitrogen isotopic shifts in shrimps (Fig. 1a). Parameters $m$ and $k$ indicated that estimated nitrogen half times in tissue ranged from $6.2 \mathrm{~d}$ in shrimp fed diet $100 \mathrm{~F}$ to $7.8 \mathrm{~d}$ in shrimp fed on diet $100 \mathrm{~S}$ (Table 3). Estimated carbon half times in muscle tissue ranged from $3.3 \mathrm{~d}$ (diet 50FSG) to $9.8 \mathrm{~d}$ (diet 100S).

\subsection{Nutritional contributions from fish meal, soy protein and corn gluten}

Isotopic changes observed over the experimental period and inclusion of asymptotic values into the isotopic mixing model (Fig. 2) indicated that, in most cases, the contributions of dietary nitrogen and carbon from FM, SP and CG to the growth of shrimps were statistically similar to the expected nutritional contributions available in the dietary formulations after correcting for ADC (Tables 1 and 4). Although differences were small, shrimps fed on diet 50GFS incorporated significantly higher amounts of dietary nitrogen (58\%), dietary carbon (66\%) and total dry matter $(66 \%)$ from CG $\left(\chi^{2}=6.2, P=0.044\right)$ and significantly less from FM. Shrimps fed on diet 50SFG also incorporated significantly higher amounts of dietary carbon and dry matter from CG $\left(\chi^{2}=7.7, P=0.020\right)$. Nutritional contributions from SP to muscle tissue were very consistent with the proportions pre-established in the respective dietary formulations.

\section{Discussion}

\subsection{Growth and survival}

In the present study, significant differences observed in growth rates among treatments cannot be attributed to the protein level of the experimental diets (36\%) as it has been reported that a dietary protein level above 32\% is optimal for early juveniles of this species (Kureshy and Davis, 2002). Likewise, all diets were supplemented with fish oil in order to avoid deficiencies of fatty acids induced in marine animals by ingredients containing low lipid levels such as CG and SP (Lewis and Kohler, 2008). Lower growth rates observed in animals fed on diets having only plant-derived protein can be explained by the nutritionally unsuitable amino acid profile of SP and CG for marine shrimp. Additionally, presence of anti-nutritional

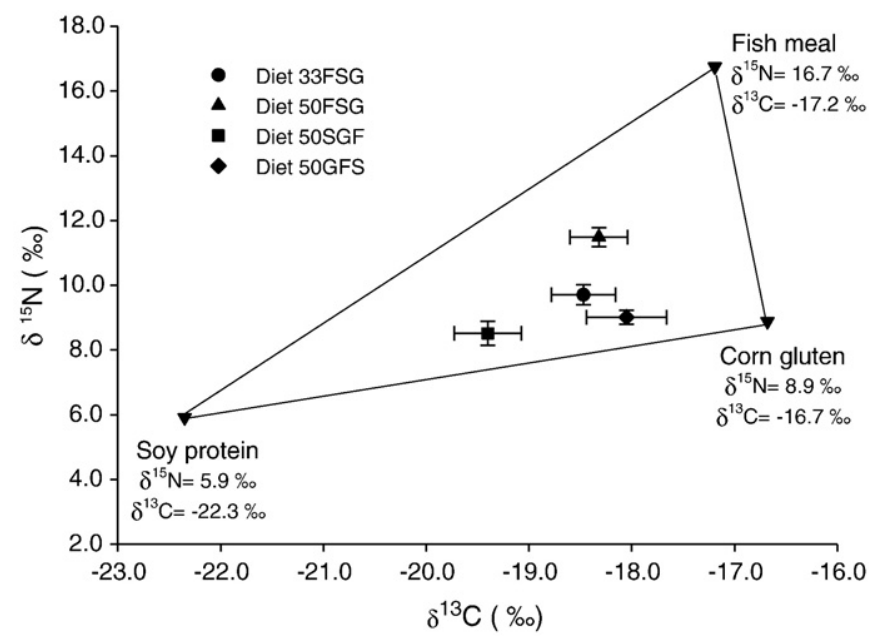

Fig. 2. Carbon and nitrogen isotope values of experimental diets (corrected for isotopic discrimination factors) and isotope values of muscle tissue of shrimps fed on four experimental diets having varying levels of fish meal, soy protein isolate and corn gluten. Mean of 9 animals per sample \pm SD. 
Table 4

Estimated relative proportions of dietary nitrogen, carbon and total dry matter supplied from fish meal, soy protein isolate and corn gluten to muscle growth of Pacific white shrimp L. vannamei as indicated by a three-source, two-isotope mixing model (mean $\pm S D, n=9$ per diet).

\begin{tabular}{|c|c|c|c|}
\hline \multirow[t]{2}{*}{ Diet } & \multicolumn{2}{|c|}{ Expected contributions } & \multirow{2}{*}{$\frac{\text { Observed contributions }}{\text { Muscle tissue }}$} \\
\hline & Bulk diet & Corrected for ADC* & \\
\hline \multicolumn{4}{|l|}{ Nitrogen } \\
\hline \multicolumn{4}{|l|}{$33 F S G$} \\
\hline Fish meal & 33.2 & $30.5^{\mathrm{a}}$ & $23.9 \pm 0.4^{\mathrm{a}}$ \\
\hline Soy protein & 33.4 & 37.6 & $35.4 \pm 1.8$ \\
\hline Corn gluten & 33.4 & 31.9 & $40.7 \pm 1.2$ \\
\hline \multicolumn{4}{|l|}{ 50FSG } \\
\hline Fish meal & 50.4 & $47.2^{\mathrm{a}}$ & $44.1 \pm 0.4^{\mathrm{a}}$ \\
\hline Soy protein & 24.7 & 28.5 & $29.1 \pm 1.6$ \\
\hline Corn gluten & 24.9 & 24.3 & $26.8 \pm 1.2$ \\
\hline \multicolumn{4}{|l|}{ 50SFG } \\
\hline Fish meal & 25.3 & $22.5^{\mathrm{a}}$ & $15.5 \pm 0.8^{\mathrm{a}}$ \\
\hline Soy protein & 49.8 & 54.4 & $53.5 \pm 1.8$ \\
\hline Corn gluten & 24.9 & 23.1 & $31.0 \pm 1.0$ \\
\hline \multicolumn{4}{|l|}{ 50GFS } \\
\hline Fish meal & 25.3 & $23.4^{\mathrm{a}}$ & $12.7 \pm 0.2^{\mathrm{b}}$ \\
\hline Soy protein & 24.9 & 28.4 & $29.2 \pm 2.4$ \\
\hline Corn gluten & 49.8 & 48.2 & $58.1 \pm 2.6$ \\
\hline \multicolumn{4}{|l|}{ Carbon } \\
\hline \multicolumn{4}{|l|}{ 33FSG } \\
\hline Fish meal & 29.8 & $27.4^{\mathrm{a}}$ & $21.8 \pm 0.4^{\mathrm{a}}$ \\
\hline Soy protein & 30.3 & 34.3 & $29.6 \pm 1.8$ \\
\hline Corn gluten & 39.9 & 38.3 & $48.6 \pm 1.4$ \\
\hline \multicolumn{4}{|l|}{ 50FSG } \\
\hline Fish meal & 46.5 & $43.6^{\mathrm{a}}$ & $41.7 \pm 0.4^{\mathrm{a}}$ \\
\hline Soy protein & 22.9 & 26.4 & $25.2 \pm 1.6$ \\
\hline Corn gluten & 30.6 & 30.0 & $33.1 \pm 1.2$ \\
\hline \multicolumn{4}{|l|}{$50 \mathrm{SFG}$} \\
\hline Fish meal & 23.6 & $21.1^{\mathrm{a}}$ & $14.8 \pm 0.8^{\mathrm{b}}$ \\
\hline Soy protein & 46.9 & 51.4 & $46.6 \pm 1.8$ \\
\hline Corn gluten & 29.5 & 27.5 & $38.6 \pm 1.0$ \\
\hline \multicolumn{4}{|l|}{ 50GFS } \\
\hline Fish meal & 21.6 & $20.1^{\mathrm{a}}$ & $11.0 \pm 0.2^{\mathrm{b}}$ \\
\hline Soy protein & 21.5 & 24.6 & $23.1 \pm 2.0$ \\
\hline Corn gluten & 56.9 & 55.3 & $65.9 \pm 2.4$ \\
\hline \multicolumn{4}{|l|}{ Total $\mathrm{DM}^{* *}$} \\
\hline \multicolumn{4}{|l|}{$33 F S G$} \\
\hline Fish meal & 34.1 & $28.3^{\mathrm{a}}$ & $26.3 \pm 0.4^{\mathrm{a}}$ \\
\hline Soy protein & 28.2 & 32.5 & $29.7 \pm 1.8$ \\
\hline Corn gluten & 37.7 & 39.2 & $44.0 \pm 1.4$ \\
\hline \multicolumn{4}{|l|}{ 50FSG } \\
\hline Fish meal & 51.4 & $44.6^{a}$ & $42.5 \pm 0.4^{\mathrm{a}}$ \\
\hline Soy protein & 20.7 & 25.0 & $25.3 \pm 1.4$ \\
\hline Corn gluten & 27.9 & 30.4 & $32.2 \pm 1.0$ \\
\hline \multicolumn{4}{|l|}{$50 \mathrm{SFG}$} \\
\hline Fish meal & 27.0 & $21.7^{\mathrm{a}}$ & $17.9 \pm 0.8^{\mathrm{b}}$ \\
\hline Soy protein & 43.8 & 48.9 & $47.0 \pm 1.8$ \\
\hline Corn gluten & 29.2 & 29.4 & $35.1 \pm 1.0$ \\
\hline \multicolumn{4}{|l|}{ 50GFS } \\
\hline Fish meal & 25.2 & $20.7^{\mathrm{a}}$ & $10.3 \pm 0.2^{\mathrm{b}}$ \\
\hline Soy protein & 20.4 & 23.3 & $23.3 \pm 2.0$ \\
\hline Corn gluten & 54.4 & 56.0 & $66.4 \pm 2.4$ \\
\hline
\end{tabular}

* ADC: Apparent digestibility coefficients. ${ }^{* *}$ Total dry matter contributions were estimated after correcting for elemental concentrations ( $\mathrm{C}$ and $\mathrm{N}$ ) available in the main ingredients. Different superscripts indicate significant differences between mean expected and observed dietary contributions.

factors in plant meals affecting growth has been previously documented, and although diets were post-conditioned, the possibility of a residual presence of protease inhibitors, lectins, phytic acid or saponins should not be discarded (Francis et al., 2001). Over the experimental period, shrimps increased their body weight in 3 to 4-fold, except animals fed on diets having only SP or CG as protein sources. These observations are in agreement to other studies that have remarked that the nutritional profile of plant-derived proteins does not fully satisfy the nutritional requirements of Penaeid shrimps when supplied at high inclusion levels (Cruz-Suarez et al., 2001;
Davis et al., 2002). The observed growth rate, in conjunction with the nitrogen turnover rates elicited by the different diets was sufficient for the dietary $\delta^{15} \mathrm{~N}$ and $\delta^{13} \mathrm{C}$ values to be reflected in muscle tissue and reach isotopic equilibrium. Results from previous studies in which FM has been replaced with plant-derived ingredients in diets for Pacific white shrimp, indicate that lower growth and survival rates are observed when the dietary levels of plant meals are high or represent the only source of protein (Galgani et al., 1988; Molina-Poveda and Morales, 2004; Paripatananont et al., 2001), such observations are consistent with the observed growth rate in shrimps fed diets containing only plant-derived meals. SP and CG are ingredients that have been previously used to replace FM in aquaculture diets for crustaceans and fish. Most studies indicate that better results in terms of biomass production, survival and hematological parameters are achieved when these ingredients have been used at low to medium replacement levels and in conjunction with other ingredients derived from plant or animal sources (Kikuchi, 1999; Lewis and Kohler, 2008; Li et al., 2012; Regost et al., 1999; Robaina et al., 1997; Sookying and Davis, 2012; Ye et al., 2011). However, successful substitution of high levels of dietary FM using plant proteins has also been reported for some marine organisms. For example, Alvarez et al. (2007) replaced up to $75 \%$ of FM with soybean meal in diets for shrimp L. schmitti without compromising weight gain, feed conversion ratio and protein efficiency ratio. In a study conducted on Senegalese sole (Solea senegalensis), Cabral et al. (2011) reported that a diet in which 75\% of FM was replaced by a mixture of plant proteins, promoted similar weight gain and protein efficiency ratio than a diet containing FM as the main protein source.

\subsection{Isotopic shifts and discrimination factors}

In the present study, SP and CG were selected for their potential to replace FM and also for having highly contrasting $\delta^{15} \mathrm{~N}$ and $\delta{ }^{13} \mathrm{C}$ values in comparison to FM. Such differences allowed formulating experimental diets with ingredients having a wide range of isotopic values, which in turn allowed exploring dietary effects on the isotopic shifts in shrimp. The isotopic values of the experimental diets were rapidly reflected in shrimp muscle tissue and isotopic steady state between diets and animals was reached between experimental days 22 and 29. As different growth rates were observed, it is assumed that animals reached isotopic equilibrium through both, tissue accretion and metabolic turnover rates. Shrimps fed on diets 100G and 100S increased their body weights by only 72 and $214 \%$, respectively; however, these animals also reached isotopic equilibrium through tissue metabolic turnover. Besides comprising more than $60 \%$ of the Penaeid shrimp body weight, abdominal muscle tissue was selected because previous studies conducted on crustaceans have shown only small differences in nitrogen isotopic ratios between muscle and whole body samples (Gamboa-Delgado and Le Vay, 2009b; GamboaDelgado et al., 2011; Stenroth et al., 2006). Such similarity also indicates that isotopic routing effects were not significant (e.g. dietary elements were not differently allocated to muscle tissue). At the end of the experiment, $\Delta{ }^{15} \mathrm{~N}$ and $\Delta^{13} \mathrm{C}$ values between shrimp and their respective experimental diets were very contrasting and ranged from 0.3 to $5.8 \%$ for nitrogen and from -0.1 to $2.7 \%$ o for carbon. Even though the $\Delta^{15} \mathrm{~N}$ and $\Delta^{13} \mathrm{C}$ values are necessary to apply correction factors in the mixing models, these isotopic discrimination factors are frequently unknown or difficult to estimate when conducting nutritional or ecological studies. Under these situations, average values are taken from the literature despite the fact that wide variations in the $\Delta^{15} \mathrm{~N}$ and $\Delta^{13} \mathrm{C}$ values have been reported (Caut et al., 2009). There is an ongoing discussion about what causes these isotopic discrimination factors, and although increasing evidence indicates that high $\Delta^{15} \mathrm{~N}$ values are related to a higher demand for specific nutrients (Le Vay and Gamboa-Delgado, 2011), is still not known if $\Delta^{15} \mathrm{~N}$ values are more affected by the quality of the available dietary protein 
(Robbins et al., 2005; Roth and Hobson, 2000) or by the protein quantity (Pearson et al., 2003). For example, in juvenile blue crabs Callinectes sapidus, high $\Delta^{15} \mathrm{~N}$ values have been associated to diets containing high C:N ratios (Fantle et al., 1999) and some authors consider that when organisms face nutritional deficiencies, they respond by increasing the metabolic cycling of nonessential nutrients, which might increase the $\Delta^{15} \mathrm{~N}$ values between animal tissue and diet (Martínez del Rio and Wolf, 2005). In this context, the higher discrimination factors observed in shrimps fed diets having only SP or only CG as protein source, could be related to the comparatively lower availability of some essential amino acids (i.e. lysine, methionine) in plant-derived ingredients.

\subsection{Nitrogen and carbon half times in muscle tissue}

Estimated half times of nitrogen and carbon in muscle tissue ranged from 3.3 to $9.8 \mathrm{~d}$ and differences were attributed to diet type. As observed in the isotopic discrimination factors, diets containing only plant-derived protein elicited different responses in the half times in tissue. Diet $100 \mathrm{~S}$ caused longer nitrogen and carbon half times in tissue ( 7.8 and $9.8 \mathrm{~d}$, respectively), while diets containing higher levels of FM (diets 100F and 50FSG) elicited shorter half times (3.3 to $6.6 \mathrm{~d}$ ), which were probably associated to higher metabolic rates caused by higher growth rates. It has been reported that the rates of protein synthesis are characteristically high in postlarval and juvenile Penaeid shrimps (Mente et al., 2002). Although the energy cost of high metabolic turnover rates and protein synthesis is substantial (Waterlow, 2006), in the present experiment the dietary energy supplied to shrimp was not limiting as all diets were formulated to have high caloric yield. Carbohydrates known to be highly digestible for this shrimp species were supplied (Cousin et al., 1996) and it is thus suggested that a restriction of specific amino acids (e.g. lysine and methionine in SP and CG) in diets formulated with plant-derived proteins caused longer nitrogen and carbon half times and lower growth rates.

\subsection{Nutrient contribution from fish meal, soy protein isolate and corn gluten}

The contrasting isotopic values of the main dietary ingredients and their introduction into the isotopic mixing model in conjunction with the isotopic values measured in shrimps, allowed estimating the relative proportional contributions of dietary nitrogen, carbon and total dry matter. Although most of the nutritional contributions to shrimp growth were statistically similar to the proportions of available nutrients in the dietary formulations, there were some differences. For example, under lower FM availability (diets 50SFG and 50GFS), there was a higher incorporation of nutrients from CG (7 to $11 \%$ more) than from FM. Diet 33FSG supplied amounts of dietary nitrogen and carbon that were similar to the proportions established in the formulated diets. Estimated proportions of assimilated total dry matter were not statistically different to the dietary proportions available in diets 33FSG and 50FSG, but there was a higher incorporation of total dry matter from CG than from FM in diets 50SFG and 50GFS. Dietary nitrogen contributions from SP to muscle tissue were high and consistent with the amounts of nitrogen available in the respective compound diets. In previous experiments applying isotopic techniques to explore dietary nitrogen contributions from plant meals to shrimp growth, high contributions of plant-derived nitrogen have been observed, although not necessarily in proportions matching the dietary availability. For example, Gamboa-Delgado and Le Vay (2009b) reported significant differences in the incorporation of FM (73\% contribution) and SP (27\% contribution) when both ingredients were included in diets supplying similar proportions of dietary nitrogen (50:50, at 46\% crude protein) for juvenile L. vannamei ( $414 \mathrm{mg}$ ). In contrast, Martínez-Rocha et al. (in press) observed that postlarval shrimp
L. vannamei (141 mg) incorporated similar amounts of dietary nitrogen from pea meal (Pisum sativum) and FM when fed on formulated diets having varying proportions of dietary nitrogen supplied from both ingredients. It is very likely that the different nutritional contributions might be explained by differences in the amino acid profiles of FM, SP and CG. While FM contains higher amounts of the essential amino acids methionine and lysine than SP (Cruz-Suárez et al., 2009), CG contains leucine at levels that are up to 2-fold higher than the levels available in FM (Terrazas et al., 2010; Villarreal-Cavazos, 2011). Besides its importance as a branch chained amino acid, studies conducted on mammals have shown that leucine is the only dietary amino acid that has the capacity to stimulate the muscle protein synthesis, hence slowing down the degradation of muscle tissue (Etzel, 2004). Higher levels of the amino acid phenylalanine are also found in CG than in FM (Terrazas et al., 2010; Villarreal-Cavazos, 2011), which might further explain the higher contributions of dietary nitrogen and carbon contributed by CG to the muscle of shrimp fed on some of the experimental formulations. It has been demonstrated in crustaceans and fish that different amino acids may significantly differ in their $\delta^{15} \mathrm{~N}$ (Schmidt et al., 2004) and $\delta^{13} \mathrm{C}$ values (McCullagh et al., 2008) in a range of up to 20 units (\%). Therefore, future nutritional studies might use this natural isotopic labeling to explore the transfer of dietary amino acids by applying compound specific isotopic analysis (CSIA) of amino acids in diets and shrimp tissues. In the present study, the estimated incorporation of nutrients into muscle tissue and the growth rates thus suggest that when FM is replaced with SP and CG at a level between 50 and 66\% (diets 33FSG and 50FSG), growth and survival rates are similar to those observed in shrimps fed on fish meal-based diets. The isotopic techniques can yield valuable information on the rates of incorporation of specific dietary nutrients in marine organisms, and results from the present study highlight the nutritional and economical benefits that plant-derived ingredients represent when supplied at dietary levels that promote complementary nutritional effects on shrimp growth.

\section{Acknowledgments}

The authors acknowledge "Maricultura del Pacífico" shrimp hatchery for kindly donating the experimental animals. We thank two anonymous referees who provided valuable comments to improve the manuscript. This study was financially supported by the Mexican Public Education Secretariat (SEP) and by the Universidad Autónoma de Nuevo León through projects PROMEP/103.5/11/4330 and PAICYT CT-292-10, respectively.

\section{References}

Alvarez, J.S., Hernandez-Llamas, A., Galindo, J., Fraga, I., Garcia, T., Villarreal, H., 2007. Substitution of fishmeal with soybean meal in practical diets for juvenile white shrimp Litopenaeus schmitti (Perez-Farfante and Kensley, 1997). Aquaculture Research 38, 689-695.

Amaya, E.A., Davis, D.A., Rouse, D.B., 2007. Replacement of fish meal in practical diets for the Pacific white shrimp (Litopenaeus vannamei) reared under pond conditions. Aquaculture 262, 291-298.

Beaudoin, C.P., Prepas, E.E., Tonn, W.M., Wassenaar, L.I., Kotak, B.G., 2001. A stable carbon and nitrogen isotope study of lake food webs in Canada's Boreal Plain. Freshwater Biology 46, 465-477.

Bodin, N., Le Loc'h, F., Hily, C., 2007. Effect of lipid removal on carbon and nitrogen stable isotopes ratios in crustacean tissues. Journal of Experimental Marine Biology and Ecology 341, 168-175.

Boecklen, W., Yarnes, C., Cook, B., James, A., 2011. On the use of stable isotopes in trophic ecology. Annual Review of Ecology, Evolution, and Systematics 42, 411-440.

Cabral, E.M., Bacelar, M., Batista, S., Castro-Cunha, M., Ozório, R.O.A., Valente, L.M.P., 2011. Replacement of fishmeal by increasing levels of plant protein blends in diets for Senegalese sole (Solea senegalensis) juveniles. Aquaculture 322-323, 74-81.

Caut, S., Angulo, E., Courchamp, F., 2009. Variation in discrimination factors $\left(\Delta^{15} \mathrm{~N}\right.$ and $\left.\Delta{ }^{13} \mathrm{C}\right)$ : the effect of diet isotopic values and applications for diet reconstruction. Journal of Applied Ecology 46, 443-453.

Cherel, Y., Hobson, K.A., Hassani, S., 2005. Isotopic discrimination between food and blood and feathers of captive penguins: implications for dietary studies in the wild. Physiological and Biochemical Zoology 78, 106-115. 
Cousin, M., Cuzon, G., Guillaume, J., AQUACOP, 1996. Digestibility of starch in Penaeus vannamei: in vivo and in vitro study on eight samples of various origins. Aquaculture 140, 361-372.

Cruz-Suarez, L., Ricque-Marie, D., Tapia-Salazar, M., McCallum, I., Hickling, D., 2001. Assesment of differently processed feed pea (Pisum sativum) meals and canola meal (Brassica sp.) in diets for blue shrimp (Litopenaeus stylirostris). Aquaculture 196, 87-104.

Cruz-Suárez, L.E., Tapia-Salazar, M., Villarreal-Cavazos, D., Beltran-Rocha, J., NietoLópez, M.G., Lemme, A., Ricque-Marie, D., 2009. Apparent dry matter, energy, protein and amino acid digestibility of four soybean ingredients in white shrimp Litopenaeus vannamei juveniles. Aquaculture 292, 87-94.

Davis, D.A., Arnold, C.R., McCallum, I., 2002. Nutritional value of feed peas (Pisum sativum) in practical diet formulations for Litopenaeus vannamei. Aquaculture Nutrition 8, 87-94.

De Niro, M.J., Epstein, S., 1978. Influence of diet on the distribution of carbon isotopes in animals. Geochimica et Cosmochiica Acta 42, 495-506.

Dennis, C.A., MacNeil, M.A., Rosati, J.Y., Pitcher, T.E., Fisk, A.T., 2010. Diet discrimination factors are inversely related to $\delta^{15} \mathrm{~N}$ and $\delta^{13} \mathrm{C}$ values of food for fish under controlled conditions. Rapid Communications in Mass Spectrometry 24, 3515-3520.

Ehleringer, J.R., Cerling, T.E., 2001. C3 and C4 photosynthesis. In: Mooney, H.A., Canadell, J.G. (Eds.), Encyclopedia of Global Environmental Change, vol. II. John Wiley and Sons, New York, NY, pp. 186-190.

Etzel, M.R., 2004. Manufacture and use of dairy protein fractions. Journal of Nutrition 134, 996S-1002S.

Fantle, M.S., Dittel, A.I., Schwalm, S., Epifanio, C.E., Fogel, M.L., 1999. A foodweb analysis of the juvenile crab Callinectes sapidus, using stable isotopes in whole animals and individual amino acids. Oecologia 120, 416-426.

FAO, 2007. The State of the World Fisheries and Aquaculture (SOFIA) 2006. FAO Fisheries and Aquaculture Department, Rome, Italy . (180 pp.).

Francis, G., Makkar, H.P.S., Becker, K., 2001. Antinutritional factors present in plantderived alternate fish feed ingredients and their effects in fish. Aquaculture 199, 197-227.

Galgani, F., Ceccaldi, H.J., AQUACOP, 1988. Effet de l'incorporation de farines de soja et de poisson dans l'aliment sur la croissance et les enzymes digestives de Penaeus vannamei. Aquatic Living Resources 1, 181-187.

Gamboa-Delgado, J., Le Vay, L., 2009a. Artemia replacement in cofeeding regimes for Mysis and postlarval stages of Litopenaeus vannamei: nutritional contribution of inert diets to tissue growth as indicated by natural carbon stable isotopes. Aquaculture 297, 128-135.

Gamboa-Delgado, Le Vay, L., 2009b. Nitrogen stable isotopes as indicators of the relative contribution of soy protein and fishmeal to tissue growth in Pacific white shrimp (Litopenaeus vannamei) fed compound diets. Aquaculture 291, $115-123$.

Gamboa-Delgado, J., Cañavate, J.P., Zerolo, R., Le Vay, L., 2008. Natural carbon stable isotope ratios as indicators of the relative contribution of live and inert diets to growth in larval Senegalese sole (Solea senegalensis). Aquaculture 280, 190-197.

Gamboa-Delgado, J., Peña-Rodríguez, A., Cruz-Suárez, L.E., Ricque, D., 2011. Assessment of nutrient allocation and metabolic turnover rate in Pacific white shrimp Litopenaeus vannamei co-fed live macroalgae Ulva clathrata and inert feed: dual stable isotope analysis. Journal of Shellfish Research 30, 969-978.

Gannes, L.Z., O'Brien, D.M., Martínez del Rio, C., 1997. Stable isotopes in animal ecology: assumptions, caveats, and a call for more laboratory experiments. Ecology 78, 1271-1276.

Harter, T., Buhrke, F., Kumar, V., Focken, U., Makkar, H.P.S., Becker, K., 2011. Substitution of fish meal by Jatropha curcas kernel meal: effects on growth performance and body composition of white leg shrimp (Penaeus vannamei). Aquaculture Nutrition 17, 542-548.

Hesslein, R.H., Hallard, K.A., Ramlal, P., 1993. Replacement of sulfur, carbon, and nitrogen in tissue of growing broad whitefish (Coregonus nasus) in response to a change in diet traced by ${ }^{34} \mathrm{~S},{ }^{13} \mathrm{C}$ and ${ }^{15} \mathrm{~N}$. Canadian Journal of Fisheries and Aquatic Sciences 50, 2071-2076.

Jomori, R.K., Ducatti, C., Carneiro, D.J., Portella, M.C., 2008. Stable carbon $\left(\delta^{13} \mathrm{C}\right)$ and nitrogen $\left(\delta^{15} \mathrm{~N}\right)$ isotopes as natural indicators of live and dry food in Piaractus mesopotamicus (Holmberg, 1887) larval tissue. Aquaculture Research 39, 370-381.

Kikuchi, K., 1999. Partial replacement of fish meal with corn gluten meal in diets for Japanese flounder (Paralichthys olivaceus). Journal of the World Aquaculture Society 30, 357-364.

Kureshy, N., Davis, D.A., 2002. Protein requirement for maintenance and maximum weight gain for the Pacific white shrimp, Litopenaeus vannamei. Aquaculture 204, 125-143.

Le Vay, L., Gamboa-Delgado, J., 2011. Naturally-occurring stable isotopes as direct measures of larval feeding efficiency, nutrient incorporation and turnover. Aquaculture 315, 95-103.

Leegood, R.C., 2002. C4 photosynthesis: principles of $\mathrm{CO}_{2}$ concentration and prospects for its introduction into C3 plants. Journal of Experimental Botany 53, 581-590.

Lewis, H.A., Kohler, C.C., 2008. Corn gluten meal partially replaces dietary fish meal without compromising growth or fatty acid composition of sunshine bass. North American Journal of Aquaculture 70, 50-60.

Li, M.H., Robinson, E.H., Oberle, D.F., Lucas, P.M., Bosworth, B.G., 2012. Evaluation of corn gluten feed and cottonseed meal as partial replacements for soybean meal and corn in diets for pond-raised hybrid catfish, Ictalurus punctatus $\times$ I. furcatus. Journal of the World Aquaculture Society 43, 107-113.

Liu, X., Ye, J., Wang, K., Kong, J., Yang, W., Zhou, L., 2012. Partial replacement of fish meal with peanut meal in practical diets for the Pacific white shrimp, Litopenaeus vannamei. Aquaculture Research 43, 745-755.
MacAvoy, S.E., Macko, S.A., Arneson, L.S., 2005. Growth versus metabolic tissue replacement in mouse tissues determined by stable carbon and nitrogen isotope analysis. Canadian Journal of Zoology 83, 631-641.

Martínez del Rio, C., Wolf, B.O., 2005. Mass-balance models for animal isotopic ecology. In: Starck, J.M., Wang, T. (Eds.), Physiological and ecological adaptations to feeding in vertebrates. Science Publishers, Enfield, NH, pp. 141-174.

Martínez del Rio, C., Wolf, N., Carleton, S.A., Gannes, L.Z., 2009. Isotopic ecology ten years after a call for more laboratory experiments. Biological Reviews 84, 91-111.

Martínez-Rocha, L., Gamboa-Delgado, J., Nieto-López, M.G., Ricque-Marie, D., CruzSuárez, L.E., in press. Incorporation of dietary nitrogen from fish meal and pea mea (Pisum sativum) in muscle tissue of Pacific white shrimp (Litopenaeus vannamei) fed low protein compound diets. Aquaculture Research. http://dx.doi.org/10.1111/j. 1365-2109.2011.03083.x.

Matsuda, H., Takenouchi, T., Tanaka, S., Watanabe, S., 2009. Relative contribution of Artemia and mussel as food for cultured middle-stage Panulirus japonicus phyllosomata as determined by stable nitrogen isotope analysis. New Zealand Journal of Marine and Freshwater Research 43, 217-224.

McCullagh, J., Gaye-Siessegger, J., Focken, U., 2008. Determination of underivatized amino acid $\delta^{13} \mathrm{C}$ by liquid chromatography/isotope ratio mass spectrometry for nutritional studies: the effect of dietary non-essential amino acid profile on the isotopic signature of individual amino acids in fish. Rapid Communications in Mass Spectrometry 22, 1817-1822.

Mente, E., Coutteau, P., Houlihan, D.F., Davidson, I., Sorgeloos, P., 2002. Protein turnover, amino acid profile and amino acid flux in juvenile shrimp Litopenaeus vannamei Boone: effects of dietary protein source. Journal of Experimental Biology 205, 3107-3122.

Molina-Poveda, C., Morales, M.E., 2004. Use of a mixture of barley-based fermented grains and wheat gluten as an alternative protein source in practical diets for Litopenaeus vannamei (Boone). Aquaculture Research 35, 1158-1165.

Newsome, S.D., Fogel, M.L., Kelly, L., Martínez Del Rio, C., 2011. Contributions of direct incorporation from diet and microbial amino acids to protein synthesis in Nile tilapia. Functional Ecology 25, 1051-1062.

O'Leary, M.H., 1988. Carbon isotopes in photosynthesis. Bioscience 38, 328-336.

Oujifard, A., Seyfabadi, J., Kenari, A.A., Rezaei, M., 2012. Fish meal replacement with rice protein concentrate in a practical diet for the Pacific white shrimp, Litopenaeus vannamei Boone, 1931. Aquaculture International 20, 117-129.

Paripatananont, T., Boonyaratpalin, M., Pengseng, P., Chotipuntu, P., 2001. Substitution of soy protein concentrate for fishmeal in diets of tiger shrimp Penaeus monodon. Aquaculture Research 32, 369-374.

Pearson, S.F., Levey, D.J., Greenberg, C.H., Martínez del Rio, C., 2003. Effects of elemental composition on the incorporation of dietary nitrogen and carbon isotopic signatures in an omnivorous songbird. Oecologia 135, 516-523.

Phillips, D.L., 2012. Converting isotope values to diet composition: the use of mixing models. Journal of Mammalogy 93, 342-352.

Phillips, D.L., Koch, P.L., 2002. Incorporating concentration dependence in stable isotope mixing models. Oecologia 130, 114-125.

Post, D.M., 2002. Using stable isotopes to estimate trophic position: models, methods, and assumptions. Ecology 83, 703-718.

Regost, C., Arzel, J., Kaushik, S.J., 1999. Partial or total replacement of fish meal by corn gluten meal in diet for turbot (Psetta maxima). Aquaculture 180, 99-117.

Robaina, L., Moyano, F.J., Izquierdo, M.S., Socorro, J., Vergara, J.M., Montero, D., 1997. Corn gluten and meat and bone meals as protein sources in diets for gilthead seabream Sparus aurata. Nutritional and histological implications. Aquaculture 157, 347-359.

Robbins, C., Felicetti, L., Sponheimer, M., 2005. The effect of dietary protein quality on nitrogen isotope discrimination in mammals and birds. Oecologia 144, 534-540.

Roth, J.D., Hobson, K.A., 2000. Stable carbon and nitrogen isotopic fractionation between diet and tissue of captive red fox: implications for dietary reconstruction. Canadian Journal of Zoology 78, 848-852.

Schmidt, K., McClelland, J.W., Mente, E., Montoya, J.P., Atkinson, A., Voss, M., 2004 Trophic-level interpretation based on $\delta^{15} \mathrm{~N}$ values: implications of tissue-specific fractionation and amino acid composition. Marine Ecology Progress Series 266, 43-58.

Sookying, D., Davis, D.A., 2012. Use of soy protein concentrate in practical diets for Pacific white shrimp (Litopenaeus vannamei) reared under field conditions. Aquaculture International 20, 357-371.

Stenroth, P., Holmqvist, N., Nyström, P., Berglund, O., Larsson, P., Granéli, W., 2006. Stable isotopes as an indicator of diet in omnivorous crayfish (Pacifastacus leniusculus): the influence of tissue, sample treatment and season. Canadian Journal of Fisheries and Aquatic Sciences 63, 821-831.

Tecator, 1983. Fat extraction on feeds with the Soxtec System HT-the influence of sample preparation and extraction media. Application note AN 67/83 (1983.06.13). Soxtec System HT Manual Tecator. Höganäs, Sweden, p. 20.

Terrazas, M., Civera, R., Ibarra, L., Goytortúa, E., 2010. Coeficientes de utilización digestiva aparente de materia seca, proteína y aminoácidos esenciales de ingredientes terrestres para el camarón del Pacífico Litopenaeus vannamei (Decapoda: Penaeidae). Revista de Biologia Tropical 58, 1561-1576.

Villarreal-Cavazos D.A., 2011. Determinación de la digestibilidad aparente de aminoácidos de ingredientes utilizados en alimentos comerciales para camarón blanco (Litopenaeus vannamei) en México. PhD Thesis. Universidad Autónoma de Nuevo León, Mexico. http://eprints.uanl.mx/2537/.

Waterlow, J.C., 2006. Protein turnover. CABI International, Oxfordshire, UK . (320 pp.)

Ye, J.-D., Wang, K., Li, F.-D., Sun, Y.-Z., Liu, X.-H., 2011. Incorporation of a mixture of meat and bone meal, poultry by-product meal, blood meal and corn gluten meal as a replacement for fish meal in practical diets of Pacific white shrimp Litopenaeus vannamei at two dietary protein levels. Aquaculture Nutrition 17, e337-e347. 